\title{
Job satisfaction levels of Turkish judo coaches
}

\author{
Selcuk Gencay and Okkes Alpaslan Gencay* \\ Department of Physical Education, School of Physical Education and Sport, Kahramanmaras Sutcu Imam University, \\ Kahramanmaras, Turkey. \\ Accepted 13 September, 2012

\begin{abstract}
The primary purpose of this study is to determine whether there is a difference in judo coaches' job satisfaction by demographic variables. Secondary purpose is to study judo coaches' job satisfaction level by occupational and work place variables. Fifty five of the subjects were males and 10 of them were females, sixty five Judo coaches in total were tested with job satisfaction questionnaire developed by Hackman and Oldham (1975). Differences among variables were examined by one way ANOVA. Alpha 0.05 was taken. It was determined in the research that there were no differences $(p>0.05)$ in job satisfaction by gender, income from coaching, daily working hours, occupational experience and work environment in judo coaches' job satisfaction level but there were differences $(p<0.05)$ by occupational view of the future, choosing the same profession and approach of the manager of business place to them.
\end{abstract}

Key words: Job satisfaction, judo coaching, sport management.

\section{INTRODUCTION}

Job satisfaction is the work value of the workers to their own professionals and an emotive reaction in consequence of the things acquired from work (Oshagbemi, 2000), whether the person likes his/her job or not and feelings for his/her job (Spector, 1997), content of the job and individual's positive attitude to work place and workers' satisfaction or dissatisfaction for the job (Ozgen et al., 2002). Job satisfaction is the individual's expectations from job and what they really acquire from the job, how much the individual cares and values for his/her job (Avci and Karatepe, 2000).

One's occupation is an important part of their life (Sunay, 2005). There have been many definitions of the term of coach. Coach is the person who trains, guides and disciplines the athletes (TDK, 1992), who obtains a certificate by completing the programs related to his/her sports brunch, who follows the developments and trains the athletes and the teams for any sports activities within his/her specialty according to national and international rules and techniques (Official Gazette, 1991).

${ }^{*}$ Corresponding author. E-mail: alpaslan@ksu.edu.tr. Tel: +90 3442129188.
According to Kazancakis (1985), a coach is the training manager of the athletes who competes for a purpose. Coaches manage their athletes for this purpose perceptively. In addition to these, coach is a fine organizer, an effective manager and a motivator (Sevim et al., 2001).

\section{LITERATURE REVIEW}

Locke (1976) give a comprehensive definition of job satisfaction as pleasurable or positive emotional state resulting from the appraisal of one's job or job experience. Job satisfaction is a result of employee's perception of how well their job provides those things that are viewed as important. Also it has been shown to positively affect job performance within a variety of work environments (Katzell et al., 1992).

The examination of job satisfaction in the general business sector has found that employees who were satisfied with their job were more likely to strive towards difficult performance goals and perform at a higher level, were more committed to the organization, accepted more responsibilities, and took on significant leadership roles (Ansari et al., 1982; Joyce and Slocum, 1982; Katzell et 
al., 1992), In contrast, dissatisfied employees felt more frustrated, made lesser efforts towards job tasks, and typically changed jobs more frequently (Joyce and Slocum, 1982),

A number of authors have emphasized that coaching is a non-traditional profession in terms of working hours and time commitment (Chalip, 1978; Dixon and Bruening, 2007). Dixon and Bruening (2007) described coaching in the following manner: The multi-faceted, high paced work setting full of practices, recruiting, offseason workouts, administrative duties and teaching responsibilities has created an environment where only those willing to work twelve hours days, six days a week, for fifty weeks a year can thrive.

Coaching jobs require long, nontraditional hours, and extensive travel. Coaches work to provide evening and weekend games and events that serve as entertainment for other members of their communities. Therefore, work often interferes directly with the coaches' own leisure time and potentially family activities as well (Chalip, 1978; Dixon and Bruening, 2007; Staines and Pleck, 1984). While coaches understand and expect these working conditions, some coaches have reported that they accept these conditions in large part because they are given flexibility with when and where they complete their work on the whole (Dixon and Bruening, 2007).

Further, the current climate of the coaching profession is that it is a year-round vocation (Brown and Little, 2001). The extensive work hours exist not only during the playing season, but for many coaches even into the months following the final game when the recruiting of new prospects is an essential component of the job (Coakley, 1986; Dixon and Bruening, 2007). Such hours continue with off-season workouts, meetings, and summer sport camps in the weeks leading up to the beginning of the season. Coaches come to expect that their "busy season" extends well-beyond the playing season itself (Brown and Little, 2001; Dixon and Bruening, 2007). This type of work establishes a subculture that the coach will be a "toiler." Doherty (1985) viewed a toiler as "one who engages in fatiguing, emotionally stressful, and ever arduous work for long hours day after day".

One of a coach's primary responsibilities is to help athletes develop as people (Chalip, 1978; Martens, 2004; Weiss and Stevens, 1993). However, such sacrifice may lead to pressure and strain within the coaching role, which may end in burnout and withdrawal (Inglis et al., 2000; Theberge, 1992; Weiss and Stevens, 1993).

As specified in these definitions, coach has an important role in athletes' and teams' achievement. Vocationally satisfied coach will train and guide the athletes better (Sunay, 2005). High job satisfaction has also been linked to personal goal attainment in sport by both coaches and athletes (Weiss and Stevens, 1993). Since job dissatisfaction has been linked to employment changes, the understanding of the coaching context could be enhanced by exploring the link between job satisfaction and burnout. Coaches with lower levels of burnout reported satisfaction in interactions with athletes, a focus on their development, rather than only considering performance outcomes (Quigley et al., 1987). Kelley and Gill (1993) also noted that job satisfaction and social support greatly reduced burnout. Thus, personal orientations towards sport, goal setting, and burnout in relation to coach job satisfaction appear to be similar to factors found in the workplace (Weinberg and Gould, 2003).

Coaches are the indispensable part of the sports. If the coaches are provided facilities as many as possible and the level of job satisfaction is increased as much as possible then the athletes will perform better. Coaches effect the athlete's achievement as well as being a skilled athlete (Yerlisu and Çelenk, 2008). Therefore coach's satisfaction and discipline have an important role in athlete's performance. Coaching is developing business in Turkey (Sunay, 2005). As in many amateur sports brunches in Turkey, the conditions provided for coaches in judo are insufficient and not at the required level and this effects the coaches' job satisfaction.

So, it is significant to determine the coaches' job satisfaction which is one of the important factors effecting a judoist achievement by different variables. The primary purpose of this study is to determine whether there is a difference in judo coaches' job satisfaction by demographic variables (gender educational level, income level). Secondary purpose is to study whether there is a difference in judo coaches' job satisfaction by occupational and work place (coaching experiences and daily working time) variables.

\section{MATERIALS AND METHODS}

\section{Sample}

The participants of the study were 65 top judo coaches in Turkey (10 females, 55 males), ages $39.26 \pm 8.81$, and $52.3 \% \quad(n=34)$ of coaches have national or international sportive success while $47.7 \%(n=31)$ have not got it. All of the participants volunteered to participate in this study.

\section{Procedures}

All of the questionnaires were administered in a lecture hall, after a national level course session. The judo coaches were told how to fill in the questionnaire, emphasizing the importance of not leaving any item unanswered. The approximate time necessary to complete the instrument was 10 to $15 \mathrm{~min}$. Incomplete or unsuitable answered questionnaires were excluded from the statistical analyses.

\section{Instruments}

\section{The job satisfaction scale}

It is developed by Hackman and Oldham (1975) to determine the level of individual's job satisfaction. The study of adaptation to 
Table 1. Demographic profiles of the judo coaches $(\mathrm{N}=65)$.

\begin{tabular}{lcc}
\hline Professional characteristics & N & $\%$ \\
\hline Gender & & \\
Male & 55 & 84.6 \\
Female & 10 & 15.4
\end{tabular}

$\begin{array}{lll}\text { Age (yrs) } & & \\ 20 \mathrm{~s} & 10 & 15.4 \\ 30 \mathrm{~s} & 23 & 35.4 \\ 40 \mathrm{~s} & 22 & 33.8 \\ 50 \mathrm{~s} & 10 & 15.4\end{array}$

$\begin{array}{lcc}\text { Educational level } & & \\ \text { Secondary school } & 2 & 3.1 \\ \text { High school } & 25 & 38.5 \\ \text { University degree } & 37 & 56.9 \\ \text { Masters } & 1 & 1.5\end{array}$

Background of athletic success

$\begin{array}{lll}\text { Yes } & 34 & 52.3 \\ 31 & 47.7\end{array}$

\section{Coaching experience}

\begin{tabular}{lll}
$1-5$ years & 14 & 21.5 \\
$6-10$ years & 18 & 27.7 \\
$11-15$ years & 12 & 18.5 \\
16 or over & 21 & 32.3 \\
\hline
\end{tabular}

Turkish and validity of the scale were carried out by Guler (1990) and internal coefficient consistence of the scale (Cronbach's alpha) was determined to be 0.96 . Job satisfaction scale is a self-report scale with 14 clauses prepared by 5 point likert technique consisting of unfinished statements. It is graded from 1 to 5 as all clauses are positive in the scale. The highest point is '70' and the lowest point is ' 14 ' to get from the scale. The points between 53 and 70 indicate the high level of job satisfaction, points between 33 and 52 indicate midlevel of job satisfaction and points between 14 and 32 indicate low level of job satisfaction. The internal coefficient consistence (Cronbach's alpha) of the job satisfaction scale with 14 questions used in present study was determined to be 0.9 and it was understood that the scale was dependable.

\section{Statistical analysis}

Acquired data in this study was analyzed using SPSS 15 package programme. Internal consistency of the questions was determined by reliability analysis (Cronbach's alpha). Means $(M)$ and standard deviations $(S D)$ of the data were calculated and when comparing independent variables and job satisfaction One Way Anova Test was used. Alpha error level was 0.05 .

\section{RESULTS}

Table 1 displays the demographic profile of the in relation to six different variables: gender, age, educational level, background of athletic success (national or international level) and coaching experience in years. $84.6 \%$ of the participants were male and $15.4 \%$ of them were female. Their ages were between 25 and 50 and they who were between 35 and 40 were predominating. We see that $56.9 \%$ of the participants were graduated. $52.3 \%$ of them had national or international sportive success in their history, $78.5 \%$ of them had occupational experience for over 6 years.

As no differences were determined in job satisfaction of the participants by gender comparing by ANOVA test $(F(1,63)=1.18, p=0.28)$, both genders were dealt in next analyses comparisons.

Job satisfaction level and educational level of Judo coaches, their coaching experiences, incomes from coaching and daily working hours were compared with one-way ANOVA test and significant differences were not determined statistically ( $p>0.05)$.

As seen in Table 2, no differences were determined in judo coaches' job satisfaction by their gender and work place. On the other hand, a significant difference was determined in job satisfaction statistically by choosing the same job, their view of future regarding their profession and the attitude of their manager $(p<0.05)$.

\section{DISCUSSION}

The primary purpose of this study to determine whether there is a difference in judo coaches' job satisfaction by demographic variables (gender educational level, income level). Secondary purpose is to study whether there is a difference in judo coaches' job satisfaction by occupational and work place (coaching experiences and daily working time) variables. For this purpose it was applied the job satisfaction questionnaire to elite level judo coaches in Turkey.

In this study there were not any significant differences determined statistically by their gender, educational level, coaching experiences, income from coaching and daily working time.

There were no significant differences determined in the job satisfaction research by their gender which was carried out in General Directorate of Youth and Sports by Ekici et al. (2009).

Yerlisu and Celenk (2008) carried out a research on volleyball coaches and they determined that coaches' education level, length of service and daily working hours had no significant effects on job satisfaction. Ulucan (2008) conducted a research on football coaches and he determined that length of service had no effects on job satisfaction. When evaluating the findings from the researches we see that similar results were obtained as the results in our study. It is seen that coaches' job satisfaction does not vary by gender, coaches' working environment, experiences and daily working hours. 
Table 2. Job satisfaction of Judo coaches by their views of coaching profession comparing with OneWay Anova test.

\begin{tabular}{|c|c|c|c|c|c|c|c|}
\hline Variable & & $\mathbf{N}$ & Mean & SD & $\mathbf{F}$ & df & sig. \\
\hline \multirow{3}{*}{$\begin{array}{l}\text { Would you choose the same } \\
\text { profession again now? }\end{array}$} & Yes & 49 & 48.5 & 9.93 & \multirow{3}{*}{13.22} & \multirow{3}{*}{ 1. 63} & \multirow{3}{*}{$0.001^{*}$} \\
\hline & No & 16 & 37.4 & 12.61 & & & \\
\hline & Total & 65 & 45.8 & 11.6 & & & \\
\hline \multirow{3}{*}{$\begin{array}{l}\text { Is your work place suitable enough to } \\
\text { do your job? }\end{array}$} & Yes & 29 & 48.1 & 10.2 & \multirow{3}{*}{2.17} & \multirow{3}{*}{ 1. 63} & \multirow{3}{*}{0.146} \\
\hline & No & 36 & 43.9 & 12.43 & & & \\
\hline & Total & 65 & 45.8 & 11.6 & & & \\
\hline \multirow{3}{*}{$\begin{array}{l}\text { Do you have any expectations } \\
\text { regarding your profession? }\end{array}$} & Yes & 35 & 48.8 & 10.5 & \multirow{3}{*}{5.52} & \multirow{3}{*}{ 1. 63} & \multirow{3}{*}{$0.022^{*}$} \\
\hline & No & 30 & 42.3 & 11.99 & & & \\
\hline & Total & 65 & 45.8 & 11.6 & & & \\
\hline \multirow{3}{*}{$\begin{array}{l}\text { Are you pleased with the attitudes of } \\
\text { your managers in your work place? }\end{array}$} & Yes & 35 & 49.8 & 10.16 & \multirow{3}{*}{10.13} & \multirow{3}{*}{ 1. 63} & \multirow{3}{*}{$0.002^{*}$} \\
\hline & No & 30 & 41.2 & 11.6 & & & \\
\hline & Total & 65 & 45.8 & 11.6 & & & \\
\hline
\end{tabular}

${ }^{*} \mathrm{p}<0.05$.

Statistically significant differences were determined in job satisfaction by choosing the same profession, their view of future regarding their profession and the attitude of their manager (Table 2). If we compare the job satisfaction of judo coaches who were pleased with the attitude of their manager in the work place with judo coaches who were not pleased with the attitude of their manager, we see that job satisfaction of the pleased judo coaches was significantly high (Table 2). This case shows similarity to the other researches carried out previously. Rao and Narayana (1998) found that managers' attitude and leadership style had an effect on increasing or reducing job satisfaction level. They stated that managers' negative attitudes could cause negative results like reluctance on the workers and resigning. According to Adesoye and Ogunnsanwo (2004), managers might acquire high performance in business by enhancing job satisfaction. Management pattern imposed by the managers has an effect on job satisfaction (Snyder, 1990). Occupational support from managers, colleagues and work environment has an effect upon job satisfaction (Soyer and Can, 2007). According to $\mathrm{Li}$ (1993), negative attitudes of the managers reduce the coaches' job satisfaction. Their positive attitudes increase the coaches' job satisfaction even under intensive working conditions.

In the conclusion of this research studying judo coaches' job satisfaction, attitudes of the managers to coaches have an effect upon judo coaches' job satisfaction. Role conflict, lack of communication in the facility and indefiniteness of the roles increase working tension and this might reduce job satisfaction. This reduces coach's performance and effects the achievement of the team or athletes and even may cause resigning of the coach (Rogers et al., 1994). Besides, understanding and approving coaches' occupational effort by their manager might have positive effects on job satisfaction ( $\mathrm{Li}, 1993)$.

Job satisfaction and dissatisfaction might have specific effects on coaches' performances. For example, dissatisfaction might have indications like not attending without any excuses, becoming ill frequently, complaining from work and resigning from work (Schmidt, 2007). The most significant of all is decrease of the coaches' job satisfaction and this effects teams' and athletes' achievement (Li, 1993). Because the coaches are the persons who have a direct contact with the athletes, a satisfied coach would train the athletes more successfully (Singh and Surujlal, 2006).

In conclusion, although this study has a few of limitations, we believe that new findings were put forward with this study and they would contribute to coaches' performances and to their achievement. We think that these findings should be supported with the future studies.

\section{REFERENCES}

Adesoye AA, Ogunnsanwo BA (2004). Importance of job satisfaction in sports organization. Publication of the Department of Human kinetics and Health Education, Unilorin. Ilorin J. Educ. Retrieved 08 Agust 2012 from http://www.unilorin.edu.ng/journals/education/ ije/dec2002/IMPORTANCE\%20OF\%20JOB\%20SATISFACTION\%20 IN\%20SPORTS\%20ORGANISATION.pdf.

Ansari MA, Baumgartel H, Sullivan G (1982). The personal orientation organizational climate fit and managerial success. Hum. Relat. 35(12):1159-1178.

Avci T, Karatepe OM (2000). Job satisfaction of the boundary-spanning role employees: An empirical assessment. Congress of the 8 . National Management and Organisation. Erciyes University, 25-27 
May, Nevsehir.

Brown M, Little B (2001). One heartbeat. New York: Bright Sky Press.

Chalip L (1978). Role conflicts in a coaching subculture. In: Hinchcliff $J$ (Ed.). The nature and meaning of sport in New Zealand. Auckland: Centre for Continuing Education, University of Auckland pp.62-65.

Coakley JJ (1986). Sport in society: Issues and controversies. St. Louis, MO: Times Mirror/ Mosby College Publishing.

Dixon MA, Bruening J (2007). Work-family conflict in coaching I: A topdown perspective. J. Sport Manag. 21:377-406.

Doherty JK (1985). Track and field omnibook. Mountain View, CA: Tafnews Press.

Ekici S, Belli E, Caliskan S (2009). Research abouth employees job satisfaction of general directorate of youth sports organization provincial level. J. Nigde University Phys. Educ. Sport Sci. 3(1):8595.

Inglis S, Danylchuk K, Pastore D (2000). Multiple realities of women's work experiences in coaching and athletic management. Women Sport Phys. Act. J. 9:1-26.

Joyce WF, Slocum J (1982). Climate discrepancy: Refining the concepts of psychological and organizational climate. Hum. Relat. 35:951-972.

Guler M (1990). Effects of depression, anxiety and some variables on industry workers' job satisfaction and job performance. [Unpublished Doctorate Thesis], Ankara: Hacettepe University Social Sciences Institute.

Hackman JR, Oldham GR (1975). Development of the job diagnostics survey. J. Appl. Psychol. 60:159-170.

Katzell RA, Thompson DE, Guzzo RA (1992). How job satisfaction and job performance are and are not linked. In: Cranny CJ, Smith PC \& Stone EF (Eds.). Job satisfaction: How people feel about their jobs and how it affects their performance. New York: Lexington Books pp.195-218.

Kazancakis N (1985). Perfect Trainer. Ankara: Neyir Publishing.

Kelley BC, Gill DL (1993). An examination of personal/situational variables, stress appraisal and burnout in collegiate teacher-coaches. Res. Q. Exerc. Sport. 64:94-102.

Li M (1993). Job satisfaction and performance of coaches of the sparetime sports schools in China. J Sport Manag. 7:132-140.

Locke EA (1976). The nature and causes of job satisfaction, Handbook of industrial and Organizational Psychology, Chicago, Rand McNally.

Martens R (2004). Successful coaching (3rd ed.). Champaign, IL: Human Kinetics.

Official Gazette (1991). Regulations of directorate of youth and sport abouth Sport experts and coach of their get their working. issue:20794.

Oshagbemi T (2000). Gender differences in the job satisfaction of university teachers. Women Manag. Rev. 15(7):331-343.

Ozgen H, Ozturk A, Yalcin A (2002). Human resources management, Ankara: Nobel Publishing.

Rao VSP, Narayana PS (1998). Organisational: theory and behaviour. Colone: Konark Publishers PVT.
Rogers JD, Clow KE, Kash TJ (1994). Increasing job satisfaction of service personnel. J. Serv. Mark. 8(1):14-26.

Quigley TA, Slack T, Smith GJ (1987). Burnout in secondary school teacher coaches. Alberta J. Educ. Res. 33:260-274.

Sevim Y, Tuncel F, Erol E, Sunay H (2001). Trainer education and principles. Ankara: Gazi Bookstore.

Singh P, Surujlal J (2006). Factors affecting the job satisfaction of South African sport coaches. S. Afr. J. Res. Sport Phys. Educ. Recreat. 28(1):127-136

Snyder CJ (1990). The effects of leader behavior and organizational climate on intercollegiate coaches' job satisfaction. J. Sport Manag. 4(1):59-70.

Soyer F, Can Y (2007). The relationship between work satisfaction with occupational expectations and accupational support: a study on the teachers of physical education. Soc. Res. J. Turkey 3:23-36.

Spector P (1997). Job satisfaction: Application, assessment, causes and consequences. Thousand Oaks, CA: Sage Publications.

Schmidt SW (2007). The relationship between satisfaction with workplace training and overall job satisfaction. Hum. Resour. Dev. Q. 18(4):481-498.

Staines G, Pleck J (1984). Nonstandard work schedules and family life. J. Appl. Psychol. 69:515-523.

Sunay H (2005). The job satisfaction of sports trainers in Turkey. Int. J. Appl. Sport Sci. 17(1):18-29.

TDK (1992). Turkish Dictionary, Turkish Language Foundation Publications. Issue: 330, Ankara.

Theberge $N$ (1992). Managing domestic work and careers: The experiences of women in coaching. Atlantis: Woman's Stud. J. 17(2): $11-21$.

Ulucan $\mathrm{H}$ (2008). A research on the job satisfaction levels of the trainers working at the infrastuctures of professional football clubs in Turkey. [Unpublished Doctorate Thesis], Ankara: Gazi University Educational Sciences Institute.

Weinberg KS, Gould D (2003). Foundations of sport and exercise psychology (3rd ed.). Champaign. IL: Human Kinetics.

Weiss M, Stevens C (1993). Motivation and attrition of female coaches: An application of social exchange theory. Sport Psychol. 7:244-261.

Yerlisu T, Celenk B (2008). Determination of job satisfaction level of volleyball trainers coaching league teams. Spormetre J. Phys. Educ. Sport Sci. 2:87-93. 